\title{
POLITICAL AND ECONOMICAL EFFECTS OF HIGHER EDUCATION REFORMS- CASE OF MACEDONIA (CRITICAL OVERVIEW ABOUT THE LAW ON HIGHER EDUCATION IN MACEDONIA)
}

\author{
Besa Kadriu ${ }^{1 *}$ and Besime Mustafi ${ }^{2}$ \\ ${ }^{1}$ PhD Assistant, Faculty of Public Administration and Political Sciences, South East European \\ University, Macedonia, e-mail: besa.kadriu@seeu.edu.mk, \\ ${ }^{2} \mathrm{PhD}$ Candidate, Faculty of Business and Economics - Economics Department, South East \\ European University, Macedonia, e-mail: b.mustafi@seeu.edu.mk
}

${ }^{*}$ Corresponding author

\begin{abstract}
Education is becoming the most important tool in societies, taking into consideration that it is positive externality that benefits the all individuals in a society. Nowadays the debate is focused towards the ways how to improve quality of teaching in higher education market. There are tendencies in Macedonia to change the law for higher education and new reforms proposed by the state are unexpected from the whole citizens. These reforms seem to be unrealistic in actually economic conditions. Macedonia as a transition country do not have capacity to cover the cost of this reforms but this politic will finish with a political and economical chaotic results. In this research paper is considered the law and its impact on economic growth and social well being. Transition countries cannot compete in higher global education market with these kind of reforms it cannot be achieved. This scientific research will have a concrete approach and analysis of the law in question by exploring the expectations and priorities of law and side effects. First of all, there will be taken into account, expectations in terms of economic and role of institutions in decision-making process in this regard. Key elements that will have a base during the research are: Reforms in education and the impact on the economic sphere and effects of the law in this case, taking into consideration the arguments given by the state and adoption of the law and policy role of the actors in this case. We conclude that to gain the global higher education market first of all it is necessary sustainable economic development. This and a number of other elements will be key issues which will be taken into account during the study.
\end{abstract}

Keywords: reform, education, law, economics, politics, government, policy.

\section{INTRODUCTION}

We are all aware that based on historical perspective and in the context of proper functioning of a state and a society, together with the realization of rules by which it will have to function or be supported, even as a 
community or particular ethnicity within a society of civilized behavior must be written based on the norm. This experience was followed long ago, since ancient civilizations in the city states (relevant policy) with the tradition of 6000 years ago. This tradition tends even to this day, especially in those countries which have a mentality and higher level in view of civilization and democracy that relies on rates written form. It later turns out also because of handling problems, as points of sensitive, culminating in the process of creating what today we know as a system of norms or creation of legal acts. Obviously in this case, the greatest responsibility lies with the institutional actors who have questioned the biggest in the area of policy and automatically in this case, the legislative body parliament is calling precisely on the issue of formulation and adoption but also the highest legal acts as may be laws. This is part within the principles and frameworks which are also implemented to countries as recognized Macedonia, known as transition and reform process that has a tendency at the last time to make appropriate changes including education. This sphere also need to develop and for that are necessary real reforms in other areas of public services and education as a sphere has very delicate matter, but that happens often in conditions which the state puts in feature of this service and within which they must operate, and when the reforms will fast forward and out opportunities then of course arises in the case of Macedonia. There are many sentences that refer to the sphere of education among which this process will pass. I will focus to one of them, deal with the "Ideally, what should be said to every child, repeatedly, throughout his or her school life is something like this: 'You are in the process of being indoctrinated. We have not yet evolved a system of education that is not a system of indoctrination. We are sorry, but it is the best we can do. What you are being taught here is an amalgam of current prejudice and the choices of this particular culture. The slightest look at history will show how impermanent these must be. You are being taught by people who have been able to accommodate themselves to a regime of thought laid down by their predecessors. It is a self perpetuating system. Those of you who are more robust and individual than others will be encouraged to leave and find ways of educating yourself - educating your own judgments. Those that stay must remember, always, and all the time, that they are being molded and patterned to fit into the narrow and particular needs of this particular society." Doris Lessing, the Golden Notebook.

\subsection{Economical \& Political Effects of Law in Education}

Macedonia as country in transition, from its independence 1991 applied a lot of reforms, both, political and economical. These reforms orient the country toward European Union. The reforms were more concentrated as the Country gain the status candidate for European Union in 2005. Education is a factor that seemed to be crucial in a society. All reforms form EU is oriented toward sustainable politics for financing education. Education has to be open equal to all. As education is as an engine that make the country to move on a lot of politicians in their programs promote education as a priority in their governance programs. As Macedonia is trying to be part of EU countries adopted a lot of reforms in education with the main aim to transform the country in European one. But sometimes the adopted reforms are not sufficient.

As countries pursue policies designed to integrate their economies, political systems and social structures under a broader, more powerful Union, it is becoming increasingly clear that higher education, research and innovation are critical components to fully realizing the potential gains stemming from the changes a head (Harry et.al 2008). Education is becoming the most powerful engine of global growth and success. It is also considered an important tool that has a great impact on the level of the country's development and growth. Public financing of education as investment is an economic issue well debated nowadays.

The reforms in education has been more designed based on political reason or drive on principle ,,more is better in state of better is more,, (populist massive education in state of quality) and not been related to the labor market need's (Bexheti et.al 2015 ). The law of higher education changes a lot from the country independence till nowadays. With the latest proposed reform in the law of higher education were organized a lot of scientific debates (local media) that have shown the importance of higher education, the matters and the ways how to improve the system of education. The proposed low in higher education (see Law for education in Macedonia) was proposed every university to incorporate the four year studies instead of three and all the curricula had to be prepared for time period of six months. Also, the master degree planned for additional two years. As the proposed law seemed to be chaotic in applying it, a lot of student, professor, academician, higher education institutions get involved in changing the proposed law. This law actually is paused for two years. The proposed law was very important as e result that a lot of things grow up for debate and all interested parties get involved in designing the new law that really can be applied and to have positive economic effects.

From the report of state statistical office in Macedonia prepared for time period 1991-2010 we dropped out a part, interesting for our case, as profiles in trade market and employed personas by educational attainment. As you can see, (table 1). In the past 20 years, the number of graduated students from higher education institutions has significantly increased - from 3384 in 1991 to 9944 in 2010, which is an increase of 194 
percent. In the period 1991-2010, a total of 99447 students have graduated. The choice of studies is closely related to the access to the labor market. The data on graduated students show that in the period from 1991 to 2010 the students show higher interest for social sciences and humanities, followed by technical, medical, biotechnical and natural sciences and mathematics. The unemployment rate moved between the same level, $82.9 \%$ in 1998 and $83.3 \%$ n 2010 showing slight upward or downward movement.

\section{Figure 1}

\section{Doctors, masters of science and science specialists}

\begin{tabular}{|c|c|c|c|c|c|c|c|c|c|c|}
\hline & & Doctor: & & & Masters & & & Speciali & & \\
\hline & all & male & female & all & male & female & all & male & female & \\
\hline 1991 & 91 & 64 & 27 & 100 & 60 & 40 & 4 & 4 & & 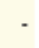 \\
\hline 1992 & 80 & 60 & 20 & 92 & 53 & 39 & . & & & \\
\hline 1993 & 38 & 26 & 12 & 67 & 32 & 35 & . & 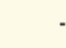 & & \\
\hline 1994 & 49 & 31 & 18 & 67 & 42 & 25 & . & 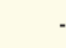 & & \\
\hline 1995 & 28 & 19 & & 66 & 36 & 30 & - & 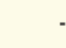 & & . \\
\hline 1996 & 51 & 33 & 18 & 43 & 21 & 22 & 1 & & & 1 \\
\hline 1997 & 56 & 41 & 15 & 77 & 40 & 37 & 1 & & & 1 \\
\hline 1998 & 51 & 31 & 20 & 73 & 35 & 38 & 3 & 2 & & 1 \\
\hline 1999 & 34 & 22 & 12 & 94 & 48 & 46 & 12 & 4 & & 8 \\
\hline 2000 & 46 & 26 & 20 & 74 & 36 & 38 & 10 & 5 & & 5 \\
\hline 2001 & 68 & 48 & 20 & 144 & 68 & 76 & 12 & 4 & & 8 \\
\hline 2002 & 51 & 23 & 28 & 87 & 41 & 46 & 9 & 2 & & 7 \\
\hline 2003 & 59 & 29 & 30 & 61 & 44 & 17 & - & 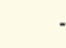 & & - \\
\hline 2004 & 67 & 35 & 32 & 106 & 66 & 40 & 4 & 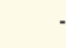 & & 4 \\
\hline 2005 & 92 & 48 & 44 & 189 & 80 & 109 & 9 & 1 & & 0 \\
\hline 2006 & 85 & 36 & 49 & 184 & 86 & 98 & 19 & 3 & & 16 \\
\hline 2007 & 82 & 39 & 40 & 272 & 109 & 163 & 5 & . & 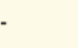 & 5 \\
\hline 2008 & 8 & 43 & 44 & 254 & 115 & 139 & 18 & 2 & & 16 \\
\hline 2009 & 119 & 55 & 64 & 412 & 179 & 233 & 13 & 7 & & 6 \\
\hline 2010 & 157 & 77 & 80 & 479 & 200 & 279 & 212 & 09 & & 103 \\
\hline
\end{tabular}

\section{Employed persons by educational attainment}

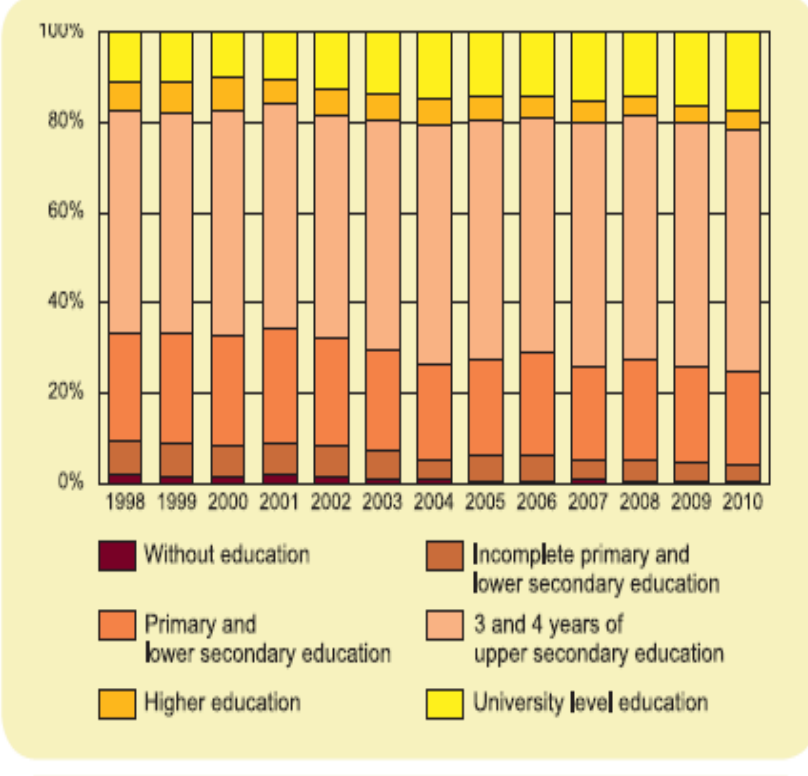

In the period 1998-2010, the participation of employees with higher education has increased continuously, from $10.8 \%$ in 1998 to $17.6 \%$ in 2010.

There were also changes in the share of unemployed persons with a particular educational attainment in the total number of unemployed persons. In 1998, the participation of unemployed persons with higher education was $4 \%$, while this participation in 2010 grew to $11 \%$.

Source: Republic of Macedonia State Statistical Office, 20 years of Independent Macedonia, Skopje, September, 2011

According to the data of the State Statistical Office, in 2014, 206 persons have gained the title "Doctor of Science", which is a decrease of $5.9 \%$ compared with 2013 . The majority of doctorate holders, $41.8 \%$, have gained their doctorate in the field of social sciences, followed by $17.5 \%$ in technical-technological sciences, $15.5 \%$ in the field of medical sciences, while the rest have obtained their doctorate in the field of humanities, natural sciences and mathematics and biotechnical sciences. The participation of females that have obtained a doctorate during 2014 was 106 candidates or $51.5 \%$ of the total number of doctorates in 2014 . Of the total number of persons that have gained the title Doctor of Science, the majority, $47.1 \%$, work in educational activity. (For more details see http://www.stat.gov.mk/pdf/2015/2.1.15.06.pdf ) A total of 2194 persons obtained the titles of Master of Science and Specialist, of which 2038 persons or $92.9 \%$ were masters of Science and 156 persons or $7.1 \%$ were specialists. Compared with 2013, the number of masters of Science and specialists increased by $31.8 \%$.

The participation of women in the total number of masters of science in 2014 was $58.5 \%$.In 2014, the majority of master's theses, 1400 or $68.7 \%$, were in the field of social sciences, followed by $15.2 \%$ in the field of technical and technological sciences, while the rest were in the fields of humanities, natural sciences 
and mathematics, biotechnical and medical sciences. The number of graduated students at higher vocational schools and faculties in 2013 decreased by $8.8 \%$ compared to 2012. The total numbers of graduates, $82.3 \%$ were full-time students, while $17.7 \%$ were part-time students. The percent of graduated female students was $56.3 \%$. Of the total number of graduated students, $40.0 \%$ has graduated on time, while $60.0 \%$ have graduated later than the official duration of education. (ibid)

As we can see from the data conducted from statistical state office all the policies in higher education brought the country in bad economical conditions. As education seemed to be crucial factor to obtain jobs and to create a sustainable economic growth in a country, In case of Macedonia we have totally different picture of education. There is a created a lot of unqualified workforce that do not comply the trade labor requirements and this is shown also from the rate of unemployment by education attainment, see figure 2 .

Figure 2

\section{Unemployed persons py equcatıonaı attainment}

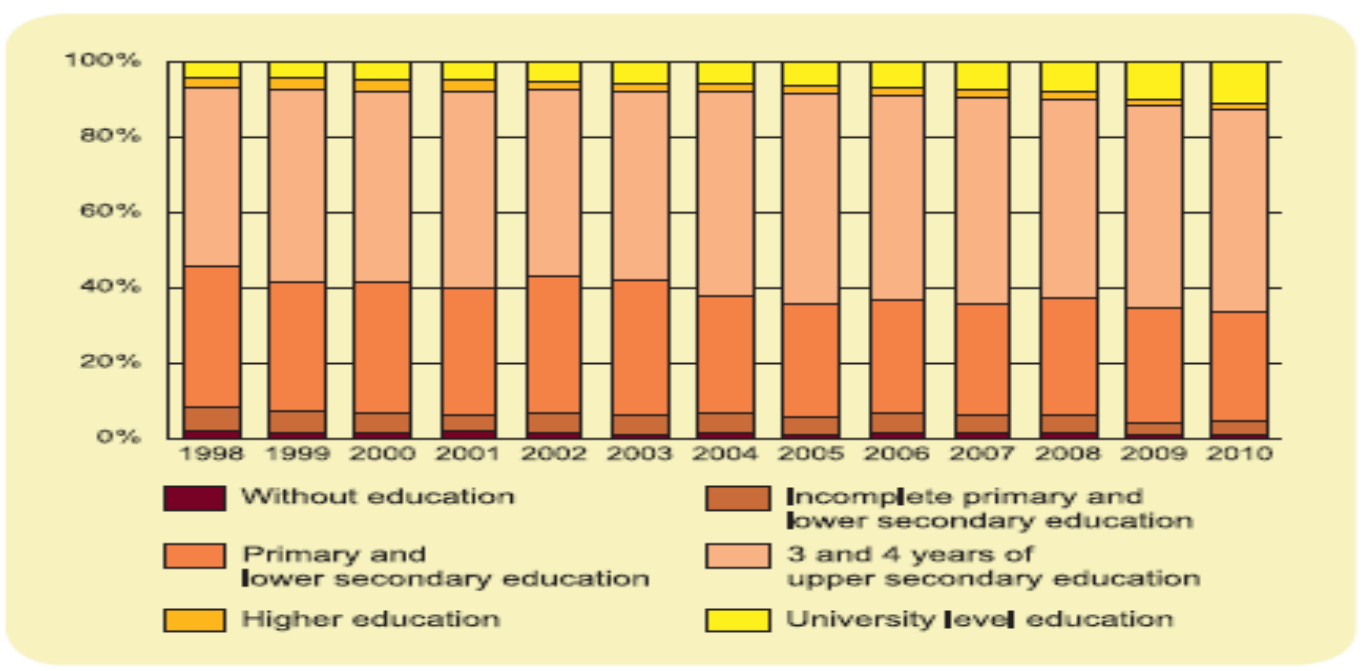

Source: Source: Republic of Macedonia State Statistical Office, 20 years of Independent Macedonia, Skopje, September, 2011

As we can see from the figure 2, the level of unemployment for workforce that hold faculty degree showed growing trends. The encouragement of education and educational activities in the last years has influenced the participation of employees with higher education in the total number of employees. This situation is harmful for the country's economic growth at all. As European Countries by Lisbon Agenda 2020 tried to make the European countries knowledge based economies but in Macedonia the reforms brought the country in contradiction of European Union view. Education is not seemed as a tool that promotes growth, contrariwise, created a 'van 'of degree holders that try to get a job outside the country. All these consequences are results from a huge numbers of private universities in a country, dispersion of universities between countries, the innumerable offerings of faculty programs, notably public universities (that offer more quotas that the number of secondary graduated schools), the law for mandatory high school, law on public servants that require 240 credits to attain a job (mandatory master degree).

To gain the competiveness in the global market, in case of Macedonia, the reforms should be oriented toward quality education policies and system, that will create skilled labor force which is accepted to fulfill the trade labor markets requirements, reducing so the rate of unemployment, reducing also the need for assistance programs from government. Rising the number of employment should been accepted to rise also the economic growth. The main policy to achieve this objective lie to secondary school and in job trainings programs. In Macedonia we need professional - productive secondary school that will orient the youth towards work that they will be more productive. Finland as a country is ranked as the first one in the world for education system as it functions in excellence. Macedonia should orient the youth toward the productive sectors for the economy. We think that in this way will be fulfilled the gap in labor market (between degree holders and trade requirements).

\section{CONCLUSIONS AND RECOMMENDATIONS}

In the past three years (2013-2015) by the Assembly of the Republic of Macedonia were adopted many proposals that were part of the Law on Higher Education in Macedonia from the Commission of Education, Science and Sport, but to all these changes require space and time for practical application! Based on the 
current conditions of the general education system in Macedonia, although trends are great for this area to change the public-service education, institutional capacity and human resources cannot meet it. The reasons may be the most cultural mediation, but will count some of them;

Firstly, any reform requires an investment for a long period of time, especially that in the field of education.

Develop a strategy for the practical implementation of the Law on Higher Education will help more the institutions for the higher education land for the application of high standards in education.

$>$ Budget dedicated to education by public funds as considerable scope of this service will help to fully realize the required standards for higher education services.

$>$ Improving relevant institutional standards that will be in the service of public and private education.

$>$ Creating standard preconditions that can be created with the realization of establishing cooperation to belong services by institutions of other countries and return of good practices in our country could be a good lesson to our new experience and will help state policy for this sensitive field as education is!

\section{REFERENCE LIST}

http://www.unibamberg.de/fileadmin/uni/fakultaeten/sowi_faecher/vwl/BERG/BERG98_Bexheti.pdf

ESMU Higher education governance reforms across the Europe, Harry de Boer and Jon File, 2008, page 7

http://www.stat.gov.mk/pdf/2015/2.1.15.06.pdf)

http://www.stat.gov.mk/

http://www.mon.gov.mk/ 